\title{
The Great War: Cinema, Propaganda, and The Emancipation of Film Language
}

\author{
Christina Stojanova \\ University of Regina (Canada) \\ E-mail: Christina.Stojanova@uregina.ca
}

\begin{abstract}
The relation between war and cinema, propaganda and cinema is a most intriguing area, located at the intersection of media studies, history and film aesthetics. A truly tragic moment in human history, the First World War was also the first to be fought before film cameras. And while in the field, airborne reconnaissance became cinematic (Virilio), domestic propaganda occupied the screen of the newly emergent national cinemas, only to see its lucid message challenged and even subverted by the fast-evolving language of cinema. Part one of this paper looks at three non-fiction films, released in 1916: Battle of Somme, With Our Heroes at the Somme (Bei unseren Helden an der Somme) and Battle of Somme (La Bataille de la Somme), as paradigmatic propaganda takes on the eponymous historical battle from British, German and French points of view. Part two analyses two war-time Hollywood melodramas, David Wark Griffith's Hearts of the World (1918) and Allen Holubar's The Heart of Humanity (1919), and explains the longevity of the former with the powerful "text effect" of the authentic wartime footage included. Thus, while these WWI propaganda works do validate Virilio's ideas of the integral connections between technology, war and cinema, and between cinema and propaganda, they also herald the emancipation of postWWI film language.
\end{abstract}

Keywords: cinema, technology, war, propaganda, film language.

\section{Introduction}

The relation between war and cinema - and more specifically between propaganda and cinema - could be traced back to the First World War (WWI), making for an intriguing interdisciplinary research area, plagued by paradoxes and controversies. Its larger philosophical, cultural and ideological context was outlined in the immediate war aftermath, when two irreconcilable discourses on technological progress were launched - a dystopian and deeply pessimistic one, associated with German Expressionism, and an optimistic and utopian one, propelled by 
Soviet Avant-garde. On film, the former is epitomized by Fritz Lang's Metropolis (Germany, 1927), which, according to German historian Philipp Blom, is the quintessential "metaphor of the threat of a world ruled by soulless technology" (Blom 2015, 177), ${ }^{1}$ of Enlightenment reason and technological progress run amok. The utopian counterpart of the world, where humans are "perfect parts" (Blom 2015, 189) living in harmony with the machines, is captured by Dziga Vertov's seminal work Man with a Movie Camera (USSR, 1929).

Blom forcefully argues that monsters like Mr. Hyde and Frankenstein were but a reflection of real-life attempts well-underway in the Soviet Union to engineer super-efficient New Men and Women, which were mirrored by the designs of Bauhaus architects to create efficient and uniform habitats. While the pessimistic view on technological progress has gradually subsided after the end of the Cold War, social thinkers like George Steiner, Slavoj Žižek and Zygmunt Bauman keep warning against complacency vis-à-vis the inevitable negative consequences of technological proliferation. Bauman, for example, traces the roots of the ubiquitous uncertainty and creative impotence - in his view, the principal features of the social malaise, gnawing at our "liquid" modernity - to WWI and its legacy of frustration with the hitherto unknown dark side of the highly praised Enlightenment values of reason and progress.

A major tragedy in modern history, WWI was also the first major man-made calamity recorded on film, paving the way towards our current disaster-asentertainment culture, described by Steiner as "casino culture," which stimulates immediate gratification and procrastination, and no longer "feels like culture of accumulation and learning ... [but] like a culture of disengagement, discontinuity and forgetting” (Bauman 2012, 117). Paul Virilio joins Bauman's social scepticism in stating that war, technology and propaganda converged for the first time during WWI. Indeed, the growing interest of the powers-that-be in the enormous mobilization potential of moving images during the war affected positively all aspects of cinema - its technology and production structure, and especially its social and cultural standing, sanctioning its ascendance from low-brow entertainment to legitimate art. Thus, the unprecedented artistic sophistication of interwar cinema in the 1920s and 1930s, as well as its formidable power as means of propaganda and persuasion, are the direct results of its achievements as industry and artistry during WWI.

Virilio proposes a model of society and media based on war, claiming that: "War is cinema and cinema is war" $(1989,26)$ and pointing out that both have

1 I am grateful to Ian Germani for suggesting the link between Virilio, Blom and dystopia. 
been symbolically represented by the search light. Virilio starts building the case against what he calls "latent totalitarianism in technology" (Kellner 1999, 104) in his previous work, Speed and Politics: An Essay on Dromology (1986) by interrogating the ever-growing role of speed - therefore dromology, the science of speed (or race) - which he traces back to the rapid development of both military technology and the cinematic apparatus circa 1904, and especially during WWI. He is particularly interested in how "innovations in speed" - or what he calls "dromocratic revolution" - "influence social and political life" (Kellner 1999, 104) since speed relates primarily to warfare and modern media, and is therefore built within the foundations of our technological society.

At the heart of Virilio's argument lies what Zygmunt Bauman calls "sociology of distance" (1989, 19-23). For Bauman, the ultimate achievement of modernity is instrumental rationality, found at its most sinister in the streamlining of death during the world wars, but especially in the Holocaust. Through various bureaucratic tactics, the perpetrators were "distanced" from their victims, construing them as "objects" of "control, manipulation, and extermination," and therefore minimizing the chances for "eruptions of moral responsibility" (Bauman 1989, 19-23). Similarly, Virilio argues, after field reconnaissance became airborne during WWI, human perspective and perception of immediacy were radically altered, making killing easier than before, and foregrounding the increasing "derealisation [or dematerialization] of military engagement" (1989, 1), which was underscored by the current high-tech virtualization of warfare "in which technologies gradually replace human beings" (Kellner 1999). Virilio believes this to be the central ethical issue of the military technologies impact, which drives progress, yet rarely in a positive direction.

Furthermore, Virilio believes that the WWI machine clearly demonstrated that the "derealization of military engagement" has simplified the connection between moving images and propaganda, since the latter is also reliant on the change of perspective and perception of immediacy. Virilio tracks down this collusion between "military and cinematic techniques and technologies" to the first "mass production of aerial photography and cinematic propaganda" during WWI (Stevenson 2008, online). Aerial photography allowed the major deviation "from shapes and representations of physical reality," leading nowadays to the "surrealist heights of unknown cinematic territory, where the old fields of perception are completely destroyed" (Virilio 1989, 27).

Following Virilio, this paper argues that WWI cast the matrix of cinema in its own image in terms of technology, ideology, and even aesthetics, shaping it as an 
advanced art form, but also as a formidable tool for oblique persuasion and direct propaganda. Indeed, because of WWI cinema shook off its questionable pedigree of a technological accident and became a legitimate art.

\section{War, European Cinemas and Propaganda}

European cinemas took their venerable place among the other arts earlier than other national cinemas worldwide, and France established itself as the uncontested leader of European film production and distribution (Toeplitz 1995, 18). Its major film companies - Pathé Frères, Gaumont, Éclipse and Éclair - had studios in nearly every European country, and enjoyed the benefits of the "truly international character of world film markets," without "quotas and protective custom barriers" (Toeplitz 1995, 18). French films were followed closely by productions from Denmark, Italy and to a much "lesser degree [films] from IMP Film of America" (Toeplitz 1995, 18).

Film language and style also evolved rapidly, introducing original forms of narrative integration and use of intertitles, new approaches to mise-en-scène and camera work such as the “'deep staging' developed by Swedish filmmakers” and the "direct address" of films made in the Netherlands (Dibbets and Hogenkamp 1995, 11). One of the most important developments in European cinemas was their move, just prior to 1914, from "fragmentary artisanal production" to "development as industry" (Toeplitz 1995, 18), which had a lasting impact on both cinema and propaganda, and induced their closeness to the state.

A consensus seems to exist that what made WWI "so destructive was propaganda," taking people "by surprise" (Bardi 2014) and the early twentieth century saw an unprecedented, world-wide "shift to massive state participation and manipulation of public opinion" (Messinger 1993, 117). Taking advantage of the "diffusion of literacy in industrialized countries," media was used "to demonize the enemy," creating a "tremendous barrage of false or distorted information" (Bardi 2014, online). However, propaganda was already a "part of life [in Britain] before 1914, but other institutions of society, such as the church, the press, business, political parties and philanthropy were its major producers - not government” (Messinger 1993, 117).

This "was the first war to be fought before motion picture cameras" (Stevenson 2008) and, since people were not prepared for the onrush of powerful images of battle, death and destruction, film increased the effect of war propaganda. And despite the British tradition of deregulated, bottom-up propaganda, state officials 
were the first to show close interest and support for "real war films," as distinct from "faked war dramas" (Reeves 1999, 28-29), a concern which was not yet on the radar of the three other warring empires. Consequently, the first state-financed War Propaganda Bureau was established in August 1914, and it launched its first film, Britain Prepared, on December 29, 1915 (Reeves 1999, 29).

\section{Part One: War, Propaganda and the Reality Effect - "Which Battle of the Somme?"}

An intriguing illustration of the interrelatedness of war, propaganda and cinema, are the three films, made about the battle on the Somme in France, the outcome of which - a source of controversy to this day - was expected to decide how the war would end. One of the bloodiest battles in history, it was fought on both sides of the river Somme between July 1 and November 18, 1916, and resulted in more than one million casualties. Each of the Newly-created propaganda offices in Britain, France and Germany made a documentary about it, claiming victory in the prolonged military campaign. ${ }^{2}$

\section{Industry}

The British Battle of the Somme ${ }^{3}$ (1916) was produced by the film department of the British War Propaganda Bureau (known by the name of its location, Wellington House) led by Charles Masterman and his team in utmost secrecy. The Wellington House films were generally timid and avoided "the hysterical hyperbole of most other forms of wartime propaganda," produced independently, "including propaganda films that have been made since” (Reeves 1999, 33). Genre-wise, this output consisted mostly of what were known as "factual" films or "actualities." The official film propagandists demonstrated aversion to the usual propaganda tricks, which would distort the truth (Reeves 1999, 30), and showed "remarkable ideological restraint," representing the events unfolding before the camera "in a measured, unemotional, almost objective manner” (Reeves 1999, 32). [Fig. 1.]

2 While the British and the German films are well preserved, available and discussed at length, the French has disappeared, which is a pity since judging by the existing commentaries, and especially by the bits and pieces that could be seen on YouTube, it looks quite intriguing.

3 The title of the film as cited in the archive of the British War Museum is Battle of the Somme, where it is filed as I [mperial] W [ar] M [useum] F [Jim] A [rchive Catalogue Number] IWMFA 191, Battle of the Somme (War Office, 1916, prod. William F. Jury), and not The Battle of the Somme as it appears in many publications, including most of the ones cited here. 
The film made a huge impression at the time of its première in Britain, ${ }^{4}$ when the battle was still far from over - it was released two months before the British offense stopped in November, on August 25, 1916, and the Manchester Guardian praised it as "the real thing at last" (Reeves 1999, 37).

Meanwhile, cameramen of the four big French companies provided propagandistic film material both domestically and internationally (Dibbets and Groot 2010, 443). Yet, as Pierre Sorlin writes, "it is difficult to explain why, in January 1917, the Ministry of War broke the agreement in place with the four film companies" and created the autonomous SPCA (Service photographique et cinématographique de l'armée [the Army's Photography and Cinema Service]), which was "under the direct authority of the government and was given the monopoly of taking pictures and films dealing with the war" $(2004,508)$. The SPCA produced La Bataille de la Somme, 1916 (The Battle of the Somme, also referred to in English as The French Offensive on the Somme, July 1916) which, according to Sorlin was a compilation, consisting of three parts, selected from the abundant pre-existing, but not yet shown footage. As Laurent Véray writes "[it] was not until 1 July 1916 [...] that cameramen were allowed to go near the line of fire to film the beginning of a real attack. The images recorded by one of them, Émile Pierre" - the cameraman of the first art film, Assassinat du Duc de Guise (1908), produced by the famous international company "Le Film d'Art" - "show French soldiers in a trench as they fix their bayonets, advance along a passage, then rush up in successive waves onto the ground above them, before disappearing into no man's land. There is nothing more moving, I think, than these men who go over the top, for we never know what becomes of them" (Véray 2010, 413).

The "French [...] did their best to outdo their ally at the cinema" (Dibbets and Groot 2010, 444), taking advantage of the delay in the British film distribution abroad. The French film, although loaned out "free of charge" by its international distributors Pathé Frères - at least in the neutral Netherlands - "failed to make a dent in film history" (Dibbets and Groot 2010, 444). And remained a subject of controversy, at the heart of which, as Sorlin believes, lies the filmmakers' misguided partisanship. The French film was thus fatally compromised by the attempt to represent a Franco-British operation without making any allusion to the part played by France's ally (Sorlin 2004, 510).

About two months after the battle, the Germans released their own official propaganda film, called Bei unseren Helden an der Somme (With Our Heroes at

4 It sold 20 million tickets in the United Kingdom during the first six weeks - meaning that half of the population saw it - a record that was broken only in 1977. 
the Somme), made in deliberate response to the British film. It lasts 51 minutes, which, as the German war film historian Rainer Rother ${ }^{5}$ writes, apparently created problems in "later releases, particularly in foreign countries" $(1983,538)$. Ironically, "the belated development of Germany's professional propaganda film unit, known as the Photograph and Film Bureau (Bild und Film-Amt or BUFA) was prompted not only by the "numerous complaints of German diplomats about the awful quality of German propaganda films," but mostly by what Rother defines as envy for the international success of "this English film”(1983, 525), with which With Our Heroes engages in implicit argument, meant to reverse the Entente claim to victory at the Somme. The importance the powers-that-be attributed to With Our Heroes explains why BUFA - proud of its first production - chose for its official inauguration the strictly PR "social event" (Rother 1983, 525) of the film premiere on January 19, 1917.

\section{Artistry}

Propaganda film units creating these Somme films demonstrates Virilio's point of the integral relatedness between film, propaganda and the state war machine. However, apart from the identical subject matter, the films do not share other common features. John Hodgkins provides a close reading of "the filmic techniques and artistry at work" in Battle of the Somme, the "potent film language" of which has been given far "little serious critical consideration" $(2008,9)$ by historians. Hodgkins argues that WWI films are overwhelmingly looked upon as historical relics, discussed with respect to their production and exhibition history and the authenticity of their images, but rarely as works of film art $(2008,9)$, being criticized for using "common cinematic tricks" and "wonders [...] an editor can create," which capitalize on "viewers' ignorance” (sic!) (Sorlin 2004, 514).

\section{A. The Question of Realism}

All three films are critiqued for lack of authenticity and confused chronologies. Such criticism is at best displaced, since the reality effect of any film is, by definition, a construct, and the question of film realism - despite the inherent indexicality of the medium - is a highly debated subject in film studies. As André Bazin claims "realism in art can only be achieved in one way - through artifice" $(1971,26)$.

$5 \quad$ Rother actually puts its length at 33 minutes, which does not include the last part of the film. 
Pragmatically, the reality effect in actualité films, especially on battlefields, is the result of the ex-prompt choices made by cameramen on the ground. Andrew Kelly quotes Geoffrey Malins - a war cinematographer and co-editor of the British Somme film - who "believed that genuine films had to show the 'suffering and agony' of conflict and present death 'in all its grim nakedness'” (1997, 48-9). Yet while their film proves that both Malins and McDowell were willing to risk their necks, ${ }^{6}$ it also implies the British command's laissez-faire attitude to both strategic military secrets and human lives. However, as Sorlin claims about the French Somme film, shooting the attacks with heavy and unyielding cameras from "a dominant frontal position" was impossible, if the scenes were not staged "during a drill," because otherwise the cameraman "would have been immediately killed by the Germans" $(2004,514)$. Discussing the German film, Rother also remarks that the assault scenes, where "the soldiers come directly towards the camera" suggest that either they are "in enemy territory" or, most likely, in "some training area" (1989, 535-536). Therefore, when Dibbets and Groot write that "the first official German propaganda film did not follow the British approach," the strength of which was in "authenticity as a point of departure," it is not exactly clear what they are accusing the film of. They do admit, however, that the British film "included a number of scenes of rather dubious authenticity" $(2010,449)$. We, as viewers, are set up to judge the nationalist bias of filmmakers from two warring sides. To accept that the British film does "include scenes of dubious authenticity," and even outright staging of soldiers going “'over-the-top' into action" (Reeves 1999, 37) means to agree that the "abstraction and symbolism" of these scenes "work to the advantage of realism." (Bazin 1971, 26.) And to reject similar tactics when exercised by the anonymous creators of the German film means to agree with Rother's brisk account that "the footage of parts two and three is staged [...] The places shown come from training areas [...] no signs to suggest anything of the Somme battlefield" $(1995,2)$. And therefore, we have to accept that the "abstraction and symbolism" of With Our Heroes "work to the detriment of realism" (Bazin 1971, 26). Which only proves the point that the ratio of authentic to staged scenes ${ }^{7}$ could not sway opinions alone one way or another, for, as Bazin writes, "in [the] name of truth [art] can only magnify or neutralize the effectiveness of the elements of reality that the camera captures"

6 For more on the self-sacrificial role of WWI cameraman, see Morrissey (2010), and Ghosts on the Somme: Filming the Battle - June-July 1916 by Alastair Fraser and Andrew Robertshaw (Pen \& Sword Military; Reprint edition, 2009-2016), dedicated to Malins and McDowell.

7 One of the most detailed researches in this vein is Roger Smithers's on Battle of Somme, who concludes that the ratio of faked to authentic scenes is "actually quite small" $(1993,160)$. 
(1971, 26). Besides, as these films are openly propagandistic, with a highly relativized question of truth, their artistic value plays a decisive role for their success or lack thereof.

Seeing the Somme films through the grid of inherent tensions between art and propaganda produces intriguing results, thanks to the friction between what Regine Robin calls "text effect" - the unfathomable poetic function of the medium or combination of creative ingenuity and reality effect, which in cinema might entail extradiegetic elements - and the "thesis effect" of the didactic or propaganda message $(1992,248)$. Hodgkins's description of the triumph of realism over didacticism in the British Somme film best illustrates the emotional impact of "text effect" over "thesis effect:" "this 'battle-field documentary,"” he writes, "was touching the hearts, minds, and bodies of wartime audiences in ways that other cinematic texts of the era - either 'factual' or fictional - were not” $(2008,12)$.

\section{B. Structure and Narrative}

Hodgkins acknowledges the high level of narrative integration in the film - its classical dramatic structure with well-defined beginning - the preparation for attack, middle - the unfolding battle, and end - the battle aftermath - supported by omniscient, suspense-building intertitles, which contribute further to its "text effect." The German film is also structured in three parts, presented as a rebuttal to the British film, but in the process sacrifices its artistic autonomy, mutating into a series of amorphous episodes. And finally, the tripartite structure of the French film seems to have been prompted solely by considerations of distribution convenience.

\section{Camera and Optics}

The uniqueness of the British film is attributed by Hodgkins to the ubiquitous point-of-view (POV) shots, and what Tom Gunning (1990) calls "cinema of attractions," ${ }^{8}$ used in relation to early cinema, which "displaces its visibility, willing to rupture a self-enclosed fictional world for a chance to solicit the attention of the spectator" $(1990,57)$. The change of perspective, introduced by the POV shot was made possible by the crash development of optics during WWI. Moreover, the perception of immediacy has mutated here into what Anne

8 The "cinema of attractions," according to Gunning, was a ruling principle of film aesthetics until 1906-1907, and then went "underground" [...], permeating the avant-garde as well as the fiction films, thus becoming "an essential part of popular film-making” (1990, 57-60). 
Rutherford calls “'corporeal vision,' thus constructing the field of vision as a tactile, and thereby affective, process" $(2002,21)$ and evoking the viewers' somatic reaction. No longer alienated observers, the audience were, as one wartime spectator put it, "in the battle and [part] of it" (Reeves 1997, 11). Furthermore, the "jolting, disorienting moments," created through ingenious editing techniques, could also be seen in terms of "the affective experience of modern, industrial warfare" (Hodgkins 2008, 17) Virilio writes about. Stressing again the intense interconnectedness between war, technology and cinema, he interprets a WWI soldier's confusion of sensations during an artillery barrage not as "a panicstricken terror but a technological vertigo or purely cinematic derealisation [...] affecting the sense of spatial dimension" (Virilio 1989, 84-85).

In comparison, the German film uses material taken by a predominantly static camera, which captures endless processions of military personnel, amassing for the assault and crossing the field of vision invariably on the diagonal from the upper left to the lower right corner of the screen. Another preferred camera position is the frontal one - either static or panning - allowing for detailed scrutiny of the intertitle claims that the images are of Entente barbarity, which has left the population at the mercy of Germans, the sole saviours here. Needless to say, these camera positions, privileging medium to long shots, preclude the intimacy of the POV shots, let alone the newly found expressivity of the lowangle ones, which the British film uses copiously in the staged scenes.

\section{Cinema of Attractions}

Known for its "elements of surprise and spectacle," which include "the newest technological wonders" and "exhibitions of violence" (Hodgkins 2008, 15), the shocking effect of the cinema of attractions aesthetics in Battle of the Somme is summarized by S. D. Badsey as the recurrence of death and waste. His notes on the "sinister 'empty battlefield' of the twentieth century," on "ghostly soldiers and monstrous guns" (1983, 113), populating "strange landscapes” (1983, 105), are most eloquent meditations on war on film. While the German and the French Somme films also rely on the "attractions" of heavy artillery equipment, both films stick to their respective propaganda agendas [Fig. 2].

Particularly important for cinema of attractions is what Gunning calls "emblematic [...] look at the camera," since it enhances the intimacy between image and viewer thus resulting in a Robin's "text effect" par excellence (Gunning 1990, 57). In Battle of the Somme, this intimacy is created by numerous grins and 
waves to the camera. Curiously, while in the British film the looks at the camera dispel the "thesis effect" by evoking not patriotic élan, but pity and fear for the lives of soldiers who are about to "fight in 20 minutes" - as one intertitle reads the looks at the camera in the German film have an opposite impact. For it is the British and French war prisoners, paraded in rows, who do the looking, few of them smiling, others shyly implying unvarnished relief. A unique moment of cinematic authenticity, the spontaneous breaking of the imaginary between themselves and the viewer, works here in support of the "thesis effect" by firming the image of German soldiers as courteous protectors of POVs. If such rare moments of truth were not drowned in redundancies and repetitions - pedantically devoted to the evacuation of enemy civilians, while intertitles rephrase the claim that "Germans protect French refugees from being fired upon by their own countrymen" - the German film might have managed to counterbalance British propaganda [Fig. 3]. Indeed, by avoiding combat scenes and especially the spectacular close-ups of "blighted landscapes" and "twisted corpses" (Hodgkins 2008, 17) that made the British film such a unique experience, the German film tends, in Virilio's words, to "dematerialise the military engagement" through visual metonyms - enemy casualties covered on stretchers or wooden crosses marking soldiers' graves thus sanitizing the omnipresence of death.

\section{The Somme Films - "Text Effect" or "Thesis Effect"?}

The première of Battle of the Somme generated "myriad interviews and newspaper reports depicting the visceral, somatic effect" the film had on viewers, describing it as "a horrifying yet profound, even spiritual, spectatorial experience" (Hodgkins $2008,11)$. It could be argued that the emotionality, triggered by the "text effect" in Battle of the Somme - the artistically most accomplished among the three Somme films - nearly destroyed its propaganda effect; and caused what Bauman (1989) calls unwanted "eruptions of moral responsibility," judging by the opinion of some viewers who "even interpreted the film, in direct contrast to the War Office view, as a plea for pacifism" (Badsey 1983, 109). On the other hand, the research of war historian Nicholas Reeves (1996) might lead us to conclude that the "text effect" reinforced the "thesis effect" since British viewers, emotionally affected by the film, manifested their sympathy for the soldiers in statements of support for the war effort. And yet, following the comments of Canadian filmmaker and essayist Donald McWilliams on the DVD release of Battle of the Somme, the propaganda effect of documentaries, "as we now know," is impossible to 
evaluate, since "viewers tend to find confirmation in what they see. It is difficult for one film to change opinion. If I see wounded being brought in and I think the war is a good thing, then I am liable to see brave young men who feel as I feel. Nonetheless, in 1916 there was an increasing disaffection with the conduct of the War. But the government decided that the gamble was worth it. The time was ripe that the public be shown something" $(2009,130)$.

The emotional film reception, both abroad and at home, questions intently Virilio's contention about the role of cinema in the "derealisation [or dematerialization] of military engagement," foregrounding the importance of film form and style in creating an emotionally realistic film experience, open to various - even contradictory - interpretations, as an alternative to a single-minded propaganda message. Whether "result of a sophisticated recognition that the images were 'able to speak for themselves"' (Reeves 1999, 33), or prompted by lenient considerations of secrecy and sheer chance, the unusually innovative aesthetic of the British Somme film displayed a respect for the image long since lost.

Neither La Bataille de la Somme nor Bei unseren Helden an der Somme went to comparable expressionist and emotional lengths in order to get their didactic points across. Deliberately dispassionate and methodical in attempting to rebuke the excessive British and French propaganda accusations of barbarism, the German film compromises the gritty novelty of its realist aesthetics against the tedium of repetitive images and intertitle messages, stifling the rare instances of "text effects" and reducing the film to an ineffective "propagandistic discourse in images" (Robin 1992, 298).

The French film, on the other hand, was meant to arouse, through shock and awe, more anger than empathy; therefore, it does not focus on the human repercussions of the battle, as the German film did, but on "presenting it as an 'objective' (i.e. without commentary) series of photographs exposing immense damage; replete with shots of burnt houses and corpses [...] highlighting the awful human and material cost of the hostilities" (Sorlin 2004, 515). As Sorlin writes, the French war actualities "contributed to forming public opinion and provided the French with a sense of what the 'Huns' would have to pay" (2004, 515), when Germany would be sued for reparations. In this sense, the "thesis effect" of La Bataille de la Somme clearly manipulated emotional involvement in the direction required by the powers-that-be, and thus, not unlike the German film, resulted in displacement of, if not in disengagement from, the military experience. 


\section{Part Two: War, Hollywood and Propaganda}

The end of war radically affected all aspects of filmmaking, tipping the balance in favour of American cinema. As The New York Times film correspondent Stuart Klawans notes, "The great victor of World War I in cinema, as in all else, was, of course, the United States. Alone among the combatants, America emerged with its society and economy intact" (2000, online). In her study of American cinema during WWI, Leslie M. DeBauche writes that the "effects of the war far outlasted the nineteen months of US involvement in the conflict," and American film industry "assumed a position of pre-eminence in the world film production" (2000, 140), by taking over "the markets from which France and Denmark have withdrawn” (Klawans 2000).

Yet first and foremost, WWI was instrumental in legitimizing the American movie industry as an important part of American society. Indeed, as Garth S. Jowett and Victoria O'Donnell write, by the end of the war, President Woodrow Wilson and other dignitaries "were not averse to being seen in the company of movie stars at war bond drives and other social occasions - something that would have been unthinkable before 1916" $(2004,109)$. This is hardly surprising, seeing the exhaustive work done in selling Liberty Bonds by such stars of the silent pre-war cinema as Mary Pickford, Charles Chaplin, Douglas Fairbanks and Theda Bara.

In order to preserve their newly acquired status, the studios were outdoing each other in producing atrocious pro-war propaganda films, among which The Battle Cry for Peace stands out with its zealousness. Produced in 1915 by Vitagraph Company of America, the film was directed by a studio co-founder, J. Stuart Blackton. Drawing on the Lusitania tragedy and released just months after it, the film was meant "to sway the American public opinion in favour of entering the war" by showing "the Germans attacking New York by sea and reducing the city to ruins" (Jowett and O’Donnell 2004, 109). Unfortunately - and regardless of its low aesthetic qualities - the film provoked an unexpectedly strong "reverse effect in that the pacifist movement used it to expose the war profiteers and armament manufacturers who would benefit from US entry into the war" (Jowett and O’Donnell 2004, 109).

After declaring war on Germany on April 6, 1917, the bulk of American propaganda films, while a "mixed lot" both aesthetically and ideologically, remained under the rubric "Hate the Hun," illustrated by titles like The Kaiser: The Beast of Berlin (Rupert Julian, 1918) and The Prussian Cur (Raoul Walsh, 1918), featuring flat characters of brutal German military personnel, who victimize 
equally flat characters of innocent civilians, usually Belgians (DeBauche 2000, 140). The only raison d'être of these simple-minded "tendentious narratives," to use David Bordwell's definition, is "to create conflicts" that both prove the propaganda thesis and "furnish narrative interest" $(1985,236)$ through dramatically justified vilification of the enemy. ${ }^{9}$ Some of the works, included in film history books, introduced more psychologically complex characters torn between their ethnic identity - Germans constituted the second-largest minority in the US at the time (Jowett and O'Donnell 2004, 210) - and their patriotic loyalties, like the father in The Hun Within (Chester Withey, 1918), who, in the name of his adopted homeland, condemns his own son as a German spy.

\section{Melodrama as Propaganda}

The most famous Hollywood-made WWI propaganda films - David Wark Griffith's Hearts of the World and Allen Holubar's The Heart of Humanity - stand out, not unlike the Somme films, because of the intriguing frictions between their "text" and "thesis effects."

Hearts of the World, subtitled A Love Story of the WWI (1918) was considered the "quintessential American World War I film" (DeBauche 2000, 140) until replaced in the 1920s by the truly anti-war pathos of King Vidor's The Big Parade (1925), William Wellman's Wings (1927) and certainly by Lewis Milestone's All Quiet on the Western Front (1930).

A co-production between two American companies - D. W. Griffith Productions and Famous Players-Lasky Corporation - and the British War Office Committee (former British War Propaganda Bureau). In its efforts to persuade the US to join the war, the Committee went as far "as to import the great American director Griffith to direct a film for them" (DeBauche 2000, 140). Advertised as "the sweetest love story ever" (DeBauche 2000, 140), Hearts of the World is defined by film historians and propaganda specialists as an exemplary achievement of Hollywood in using motion picture as a propaganda device.

Like most of Griffith's films this is a melodrama, the generic narrative economy of which effectively supports the propaganda message through extreme polarization of characters as good Americans and bad Germans. According to Thomas Elsaesser melodrama as a "popular cultural form," takes a "severe social

9 Famous film director Raoul Walsh, who made a number of anti-German pro-war films under the pressure of FOX studios in 1918, called The Prussian Cur his "rottenest picture ever." http:// www.imdb.com/title/tt0009524/trivia?ref_=tt_trv_trv. Last accessed 15. 07. 2017. 
crisis" - in this case war - and "mediates it within the private context" (Elssaesser qtd. in Hayward 2013, 230) of a fictitious French village, dividing the characters strictly into victims, villains and heroes/ saviours.

The narrative falls into four distinctive parts, representing a string of carefully planned and emotionally charged coincidences. Part one introduces the Boy and Girl - implying the generic all-American boy and girl, played by Griffith's favourite young stars, Robert Harron and Lilian Gish - who live in a French village, fall in love and are about to be married, when the war is declared [Fig. 4].

He then joins the French army as a volunteer, while she becomes a nurse. Part two moves from "the world outside" of British and French Parliaments declarations of war to the events in the village on the front. On the first day of battle, coinciding with their wedding day, the boy gets shell-shocked and the girl, "clutching her wedding dress across a desolated battlefield" (DeBauche 2000, 143), spends the night by his side thinking him dead. Part three focuses on the victims - predominantly women, old people and children - and their suffering and humiliation. While Germans are shown fooling around with handgrenades, beating the Girl into working harder and enjoying prostitutes and trophy wine, a certain von Strohm, the local German bully - sporting an elaborate Kaiser moustache, a physiognomic trait of cinematic Huns - graduates into the principal villain by attempting to rape the Girl. He catches her stealing food for the Boy's orphaned younger siblings at the local inn of another German national. Naturally, the Boy saves the day after single-handedly frustrating the German counteroffensive, pretending to be one of their own. The final part of the film is devoted to last minute rescues, surprises and recognitions, yet the happy ending comes only with the triumphant arrival of the Americans, drowning the screen in stars-and-stripes [Fig. 5]. If any "text effect" has survived Griffith's tightly controlled "tendentious narrative," it is because of what Bazin calls "aesthetic catalyst," or skilful "integration of unobtrusive elements of reality" into this otherwise "highly stylized work" $(1967,111)$ [Fig. 6].

Thus, the whole military spectacle of technology, war and death, complete with unsolicited looks at the camera, are used here as backdrops or as a side show at best. And yet, even with their emotional potential curtailed, pushing the visceral images of war into the cinematic distance via medium to long shots, these images still capture the "auratic aspect of the pro-filmic reality," which "ruptures or short-circuits" the formulaic story, "producing an affect of pure temporal distance, of materiality and its loss" (Stojanova 2011, 132). 


\section{Propaganda as Melodrama}

After a period of long neglect, ${ }^{10}$ The Heart of Humanity has lately generated newly found interest, mostly in comparison to Griffith's film. Produced by Carl Laemmle's Universal Pictures and premiered on February 15, 1919, the film was a smashing success. It is directed by Allen Holubar, but recent biographers of Erich von Stroheim, who stars in the film (Koszarski 2000), insist that he was the hidden creative force ${ }^{11}$ behind the film as he needed to impress Laemmle into producing his first three films. ${ }^{12}$ The film looks like upping the antes of Hearts of the World, especially regarding its "cinema of attractions" attributes. Indeed, for the spectacle of military technological wonders, Holubar went literally above and beyond the call of duty, providing aerial views of the battle scenes, staged at the Universal studios, and juxtaposed them to accurately reproduced moments from the heroic assault of Canadian troops at Vimy Ridge. Apart from instances of stars-and-stripes waving, which look silly in a film about an all-Canadian victory, the war spectacle would be near-perfect, if it were not lacking the flair of authenticity of military engagements and participants, which contributed so much to the historical success - and longevity - of Griffith's film. No gawking at the camera in Holubar's film, only studio-shot exchanges between actors, trying to pretend they are in the trenches.

The "cinema of attractions" penchant for shocking display of violence and death, morph here into scenes, highly suggestive of sexual violation, thanks to the presence of Erich von Stroheim as the malicious Hun. By 1918 the actor had already played Huns, yet in The Heart of Humanity he is more than the stereotypically nasty German officer, the Hun you love to hate; he is the sublime villain! His von Eberhard - a deliberate pun on the actor's name - makes von Strohm look like the village moron. ${ }^{13}$ Stroheim becomes the focus of the film early on as his is the only character to evolve - from bad to worse to be sure - as compared to the exemplary Canadian Patricia family, consisting of a virtuous and patriotic "momsey" and her five sons. It remains a mystery why John (Robert Anderson), the eldest Patricia

10 There has been only one $16 \mathrm{~mm}$ copy preserved at the Library of Congress before it was transferred on DVD.

11 Stroheim is listed as "technical assistant" in the film's credits.

12 Blind Husbands (1919), The Devil's Passkey (1920) and Foolish Wives (1922).

13 The role in Holbar's film inaugurated Stroheim as the quintessential Prussian officer for decades to come, but also led to La grande illusion/ The Grand Illusion (1937), where - cast against type by director Jean Renoir in his powerful anti-war drama - he played the upright German officer Captain von Rauffenstein, whose outdated chivalry is a memorable nod to the vanished noblesse of the belle époque. 
brother, brings Eberhard to their settlement in the Canadian Rockies on the eve of war, but apparently historical viewers were more tolerant to the needs of the "tendentious narrative," since many propaganda films of that time feature Germans visiting Entente countries ${ }^{14}$ only to be unmasked as wicked brutes when the war starts. Once with the Patricias, Eberhard begins courting John's love interest, Nanette (Dorothy Phillips), with that mixture of lechery and worldly sophistication, considered lethal for the morals of inexperienced girls. So powerfully authentic is Stroheim's presence that the sexual chemistry between him and Phillips is almost palpable in their meeting at the Virgin's shrine in the woods. Nanette, respiring heavily, pretends to ignore von Eberhard's advances, and looking at the statue of Virgin Mary, says "religion is my strength." To which he retorts with Nietzschean flair, "strength is religion in itself," while giving her his trade-mark ice-cold stare through the glinting monocle. And, as film archivist Paulo Cherchi Usai writes, the camera then "cuts to a detail of the sacred statue, where a spider has built its web around the head and the breasts of the Virgin" (1995, 248), supposedly warning against the unholy and seditious German influence. However, the "abstraction and symbolism" of the scene, in Bazin's words, work in the opposite direction and, as a result of their forceful "text effect," suggest instead a forbidden, and therefore irresistible sexual attraction between the two. [Fig. 7.]

As the film proceeds, Stroheim's presence increasingly dominates the narrative, challenging its propaganda message, especially vis-à-vis Anderson, who is stuck here with nothing to act but pose as the picture-perfect war hero. Unlike his four brothers, from whom he is physically and psychologically almost indistinguishable, John remains alive until the happy end since his sole narrative raison d'être is to save Nanette, now his wife and Junior's mother, by killing von Eberhard seconds before he succeeds in his macabre design. The infamous attempted rape episode takes the voyeuristic potential of Griffith's analogous scene to hitherto unthinkable heights. The action evolves in Vimy and environs, where Nanette is stationed as a Red Cross nurse, helping war orphans. Once Eberhard spots her in the mayhem of the fallen city, he pays his respects, helps her up the stairs to her room, and then proceeds with melodramatic impiety to tear at her clothes. And when the baby in her care starts crying, he tosses it out the window! The arousing overtones of the episode, and especially its length, transgress the premise of innocence unprotected and begin to resemble rather a hysterical projection of repressed fears and desires. Which explains the smashing success of the film, but makes its propaganda message highly suspect.

14 Another famous example is Cecil B. DeMille/ Mary Pickford's The Little American (1917). 
Along with Stroheim's mesmerizing presence, scholars ascribe the renewed interest in The Heart of Humanity to its innovative stylistic strategies which, judging by Stroheim's subsequent films as director, could be attributed to him. Usai singles out the meta-cinematic episode, where the Vimy Ridge battle is framed as a newsreel, covering both warring sides, and has von Eberhard interviewed, standing "in the middle of a trench [...] talking to a newsreel cameraman" (1995, 247). He introduces himself, while staring icily through his monocle at the camera - that is, at the viewer - uttering with menacing calmness: "Paris in a week - then London - and then, America!” The realistic setting and genuine feel of this scene obviously capitalized on historical viewers' trust in newsreel war coverage. A "revealing example of contamination between fictional film and non-fictional aesthetics" (Usai 1995, 246), the self-reflexivity of this episode would have had - if it lasted longer - a much stronger effect on audiences than Stroheim's melodramatic escapades.

Even more intriguing is the creation of a time and space solely through editing, a technique, which would reveal its full propaganda potential in the films of the Soviet Avant-garde in the 1920s. The interconnection between Nanette's compassionate nature and the suffering war infants, for example, is presented by splicing separate images of shabbily dressed tearful kids and medium shots of Phillips's expressive face. And although no establishing shot of the two parties together is ever offered, the viewer - disoriented by the change of perspective remains convinced that they share the same space.

\section{Conclusion: (Post) War Film Industries, Experimentation and Propaganda}

Understandably, not all belligerent countries grasped the mobilization potential of cinema with equal fervour and mastery. And yet, regarding the endemic interrelatedness between state, cinema and propaganda, Klawans writes, "the war's losers came out far ahead of the winners" (2008, online). Indeed, while WWI facilitated the international dissemination of American films, establishing Hollywood classical style as a model, which "other national cinemas emulated or reacted against for decades" (DeBauche 2000, 140), it also nurtured the counterbalancing impetus towards state-directed film industries, which emerged in Europe prior to and during the war, but flourished in its aftermath, and accounted for the artistic resilience of most European interwar cinemas, as well as the policies protecting their film markets. The contradictory results of these 
policies are best reflected by the artistic successes of German and Soviet cinemas in the 1920s, and by their totalitarian propaganda output in the 1930s. Thus, as Ramona Curry writes: "notwithstanding the outcomes [...] of the Versailles Treaty, the German film industry emerged [...] a winner over competing European industries, turning the comparative German business isolation and the wartime circumstance to productive advantage" (1995, 143-144).

Russia however is the more interesting case, providing a textbook illustration of the interdependency between war, cinema, propaganda and a state-run film industry. According to Peter Kenez, "the Russian Monarchy did not consider it was their task to convince people; it naively believed that it was the responsibility of people to obey and follow" $(1995,36)$. Therefore, a state-run film propaganda model, proposed by a certain V. M. Dementiev, was overlooked. An ultrareactionary politician, he was an unlikely defender of cinema since he considered it demeaning. He realized however, not unlike Lenin, that moving images were the best way to reach the mostly illiterate Russian population. In his pamphlet Cinematography as Government Regalia, published in 1915, Dementiev argues that "cinema must be nationalized and used by government as a monopoly, similar to the vodka monopoly" (Kenez 1995, 41). Being "far ahead of his time in his awareness of the propaganda potential" of cinema, Dementiev insisted that "competing views should be suppressed," and "government control should be established over thinking citizens" (Kenez 1995, 41). His ideas were brought to fruition by Lenin who, despite his contempt for cinema as a lowly art, came to a similar realization and decreed full nationalization of the chaotic Russian film industry only two years after the Bolshevik revolution, in 1919.

Yet before turning into propaganda hot-beds in the 1930s, both Goskino ${ }^{15}$ and UFA watched over the development of remarkable experimental trends, the Soviet Montage and German Expressionism. Together with the two other significant postWWI avant-garde movements - French Surrealism and French Impressionism, which advanced film language in the direction of depth of field, subjective POV shots, and complex framing and composition - Soviet Montage and German Expressionism demonstrated that war-related technological advancements of cinematic equipment - lighter cameras and better optics - propel unconventional aesthetics of filmmaking. And while German Expressionism applied its innovative stylistic devices, immersed in the graphic arts and Freudian psychoanalysis, to illuminate dark corners of the tormented German soul and to prophesize according to its most sensational theoretician Siegfried Kracauer (2004) - the

15 Renamed later Sovkino, Soyuzkino and again Goskino. 
advent of Fascism, French Surrealism, paired with Dadaism, challenged the very foundations of a world based on reason and enlightenment, exposing its "deep anxieties [...] fear and suspicion [...] and simmering hatred" (Blom 2015, 194). Promptly labelled "degenerate art" by the Nazis after 1933, German Expressionism, Surrealism and Dadaism - while summarily replaced by a return, strongly encouraged by the totalitarian establishment, to representational, figurative art - have indelibly shaped the pessimistic, anti-rational and antiestablishment panache of Modern and post-Modern art.

The achievements of Soviet Montage School - while rejected and even criminalized after 1934 by the nascent Soviet totalitarianism in favour of stateimposed Socialist Realist aesthetics - remain paradoxically relevant to Virilio's ideas because of their technological positivist pedigree. Defined by Virilio as a "visual expression of Marxist dialectic in art," Soviet Montage practices are indeed explained in military terms by Sergei Eisenstein, the most versatile practitioner and theoretician of Soviet Montage, as "collision or conflict [between two montage frames]" (Virilio 1989, 27). Another Montage School champion, Dziga Vertov, also uses military jargon to describe his camera optics as an "all penetrating eye” or an “armed eye” (Virilio 1989, 20). Paradoxically, while Vertov's experimental films, especially A Man with a Movie Camera, were neglected after 1934, they have nowadays become desktop manuals not only for film propaganda scholars and filmmakers, but also for advertisers. Today, his experiments, which do manifest the ultimate "deviation" from habitual "shapes and representations of physical reality" (Virilio 1989, 27), endure as basic points of reference for new media gurus like Lev Manovich (2001) [Fig. 12].

Catalysed by the WWI turmoil and refined in its aftermath, the swiftly evolving international language of cinema has not only validated Virilio's ideas of the integral connection between technology, war and cinema, as well as between cinema and propaganda but, as argued above, has challenged, deconstructed and even subverted them. Thanks to its exceptional and ever-evolving level of sophistication, film language has long transcended its subordinate and strictly instrumental role in construing the film message. In its current capacity of a quintessential audio-visual metalanguage, it occupies a decisive place as subject, object and means of self-reflection in the meaning-making process, particularly important in one of the most urgent philosophical and cultural debates of our time, that of technological progress and its consequences. 


\section{References:}

Badsey, S. D. 1983. Battle of the Somme: British War-Propaganda. Historical Journal of Film, Radio and Television vol. 3, no. 2: 99-115.

Bardi, Ugo. 2014. The WWI and the Rise of Propaganda. http://cassandralegacy. blogspot.ca/2014/07/the-great-war-and-rise-of-propaganda.html.

Last accessed 30. 06. 2015.

Bauman, Zygmunt. 1989. Modernity and the Holocaust. Cambridge: Polity Press.

Bauman, Zygmunt and Riccardo Mazzeo. 2012. On Education: Conversations with Riccardo Mazzeo. Cambridge: Polity Press.

Bazin, André. 1967. What is Cinema? Vol I. University of California Press.

Bazin, André. 1971. What is Cinema? Vol II. University of California Press.

Blom, Philipp. 2015. Fracture: Life and Culture in the West, 1918-1938. New York: Basic Books.

Bordwell, David. 1985. Narration in the Fiction Film. Wisconsin: University of Wisconsin Press.

Curry, Ramona. 1995. How Early German Film Stars Helped Sell the War(es). In Film and the First World War, eds. Karel Dibbets and Bert Hogenkamp, 139148. Amsterdam: Amsterdam University Press.

DeBauche, Leslie M. 2000. The United States' Film Industry and World War One. In The First World War and Popular Cinema: 1914 to the Present, ed. Michael Paris, 138-161. New Brunswick, NJ: Rutgers University Press.

Dibbets, Karel and Bert Hogenkamp. 1995. Introduction. In Film and the First World War, 10-15. Amsterdam: Amsterdam University Press.

Dibbets, Karel and Wouter Groot. 2010. Which Battle of the Somme? War and neutrality in Dutch cinemas, 1914-1918. Film History vol. 22, no. 4, Cinema During the Great War: 440-452. Indiana University Press.

Gunning, Tom. 1990. The Cinema of Attractions: Early Film, its Spectator and the Avant-Garde. In Early Cinema: Space, Frame, Narrative, eds. Thomas Elsaesser and Adam Barker, 56-62. London: BFI Publishing.

Hayward, Susan. 2013. Key Concepts in Cinema Studies. London and New York: Routledge.

Hodgkins, John. 2008. Hearts and Minds and Bodies: Reconsidering the Cinematic Language of The Battle of the Somme. Film \& History: An Interdisciplinary Journal of Film and Television Studies vol. 38, no. 1. (Spring): 9-19.

Jowett, Garth S. and Victoria O’Donnell. 2004. Propaganda and Persuasion. Los Angeles, London: Sage Publications. 
Kellner, Douglas. Virilio, War, and Technology: Some Critical Reflections. http:// www.gseis.ucla.edu/faculty/kellner/kellner.html. Last accessed 25. 06. 2017.

Kelly, Andrew. 1997. Cinema and the Great War. London: Routledge.

Kenez, Peter. 1995. Russian Patriotic Films. In Film and the First World War, eds. Karel Dibbets and Bert Hogenkamp, 36-42. Amsterdam: Amsterdam University Press.

Klawans, Stuart. 2000. How the First World War Changed Movies Forever. New York Times. http://www.nytimes.com/2000/11/19/movies/film-how-the-firstworld. Last accessed 30. 06. 2017.

Koszarski, Richard. 2004. Von - The Life and Films of Erich Von Stroheim. Limelight Editions.

Kracauer, Siegfried. 2004 [1947]. From Caligari to Hitler: A Psychological History of German Film. Princeton: Princeton Classic Editions.

Manovich, Lev. 2001. The Language of New Media. Cambridge, MA: MIT Press.

McWilliams, Donald. 2009. The Battle of the Somme. Journal of Film Preservation (International Federation of Film Archives) vol. 79/80, no. 5: 130-133.

Messinger, Gary S. 1993. An Inheritance Worth Remembering: the British Approach to Official Propaganda During the First World War. Historical Journal of Film, Radio and Television vol. 13, no. 2: 117-127.

Morrissey, Priska. 2010. Out of the Shadows: The Impact of the First World War on the Status of Studio Cameramen. Film History vol. 22, no. 4, Cinema During the Great War: 479-487. Indiana University Press.

Reeves, Nicholas. 1996. Through the Eye of the Camera: Contemporary Cinema Audiences and Their Experience of War in the Film Battle of the Somme. In Facing Armageddon: The First World War Experienced, eds. Hugh Cecil and Peter H. Liddle, 780-798. London: Leo Cooper.

Reeves, Nicholas. 1997. Cinema, Spectatorship and Propaganda: Battle of the Somme (1916) and its Contemporary Audience. Historical Journal of Film, Radio and Television vol. 17, no. 1: 5-28.

Reeves, Nicholas. 1999. Official British Film Propaganda. In The First World War and Popular Cinema: 1914 to the Present, ed. Michael Paris, 27-50. New Brunswick, NJ: Rutgers University Press.

Robin, Regine. 1992. Socialist Realism: An Impossible Aesthetics. Stanford University Press.

Rother, Rainer. 1995. "Bei unseren Helden an der Somme" (1917): the creation of a "social event." Historical Journal of Film, Radio and Television vol. 15, no. 4: 525-542. 
Rutherford, Anne. 2002. Cinema and Embodied Affect. Senses of Cinema. http://www.sensesofcinema.com/contents/03/25/embodied_affect.html. Last accessed 10. 08. 2017.

Smithers, Roger. 1993. A Wonderful Idea of the Fighting: The Question of Fakes in The Battle of the Somme. Historical Journal of Film, Television and Radio vol. 13, no. 2: 149-168.

Stevenson, Michael. 2008. Notes on Paul Virilio's War and Cinema. http:// mastersofmedia.hum.uva.nl/2008/03/10/notes-on-paul-virilios-war-andcinema/ Last accessed 30. 06. 2017.

Stojanova, Christina. 2011. Beyond Text and Image: Péter Forgács and his Wittgenstein Tractatus. In Wittgenstein at the Movies: Cinematic Investigations, eds. C. Stojanova and Béla Szabados. Lexington Books.

Sorlin, Pierre. 2004. The French Newsreels of the First World War. Historical Journal of Film, Radio and Television vol. 24, no. 4: 507-515.

Toeplitz, Jerzy. 1995. The Cinema in Eastern and Central Europe Before the Guns of August. In Film and the First World War, eds. Karel Dibbets and Bert Hogenkamp, 17-27. Amsterdam: Amsterdam University Press.

Usai, Paolo Cherchi. 1995. An Archival View. In Film and the First World War, eds. Karel Dibbets and Bert Hogenkamp, 237-249. Amsterdam: Amsterdam University Press.

Véray, Laurent. 2010. 1914-1918, the First Media War of the Twentieth Century: The Example of French Newsreels. Film History vol. 22, no. 4, Cinema During the Great War: 408-425.

Virilio, Paul. 1986. Speed and Politics: An Essay on Dromology. Columbia University.

Virilio, Paul. 1989. War and Cinema: The Logistics of Perception. London: Verso. 


\section{List of Figures}

Figure 1. Still image from the film The Battle of the Somme (1916) showing a staged attack. Believed to be shot before the opening of the battle on the $1^{\text {st }}$ of July 1916, possibly at a trench mortar school behind the lines. (Source: https:// commons.wikimedia.org/wiki/File:The_Battle_of_the_Somme_film_image1.jpg. Last accessed 04. 10. 2015.)

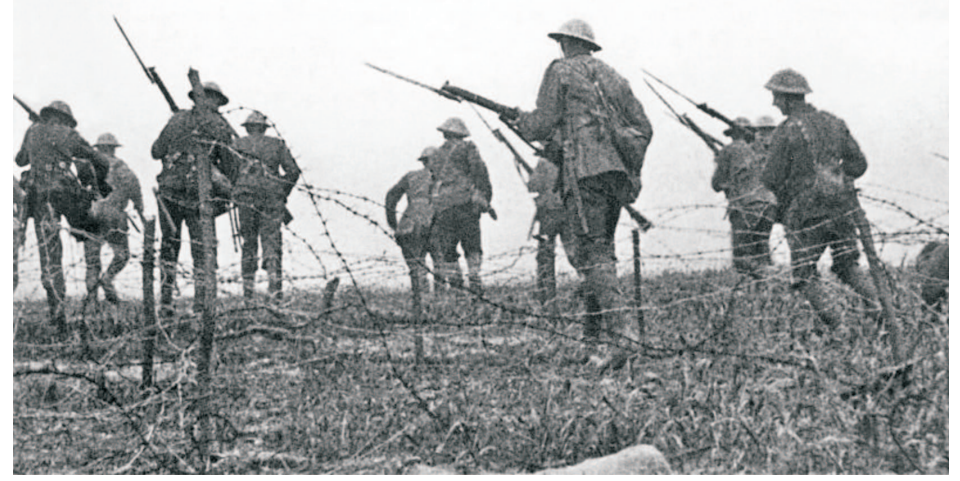

Figure 2. Still image from The Battle of the Somme showing a wounded soldier being carried through a trench. The accompanying inter-title frame reads: British Tommies rescuing a comrade under shell fire. (This man died 30 minutes after reaching the trenches.) (Source: https://commons.wikimedia.org/wiki/File:The_ Battle_of_the_Somme_film_image2.jpg. Last accessed 04. 10. 2015.)

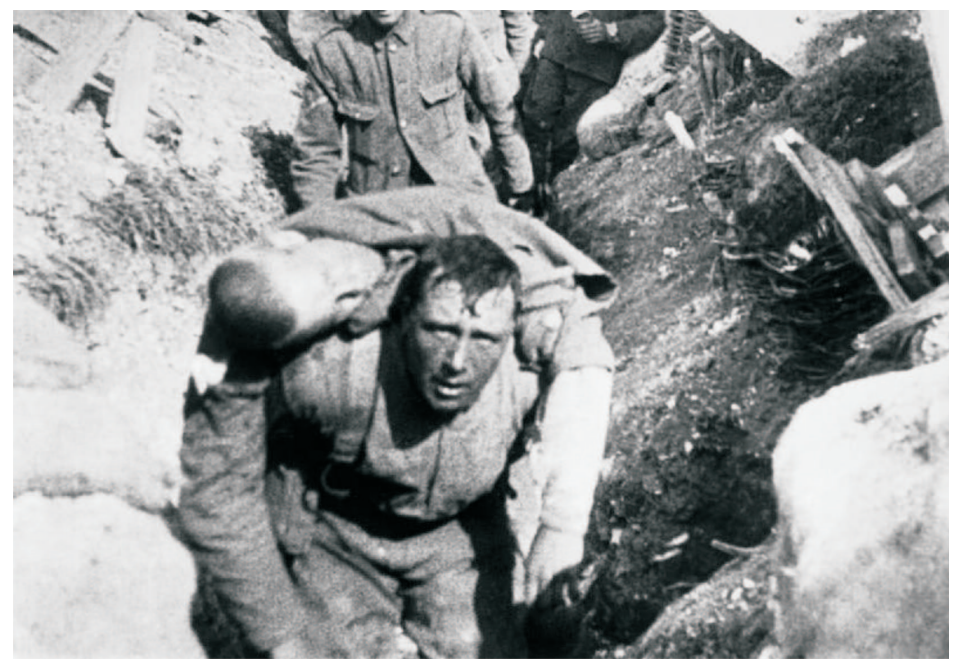


Figure 3. Bei unseren Helden an der Somme (1917, Germany): prisoners of war. (Source: http://www.kinokalender.com/film10191_bei-unseren-helden-an-dersomme.html. Last accessed 04. 10. 2015.)

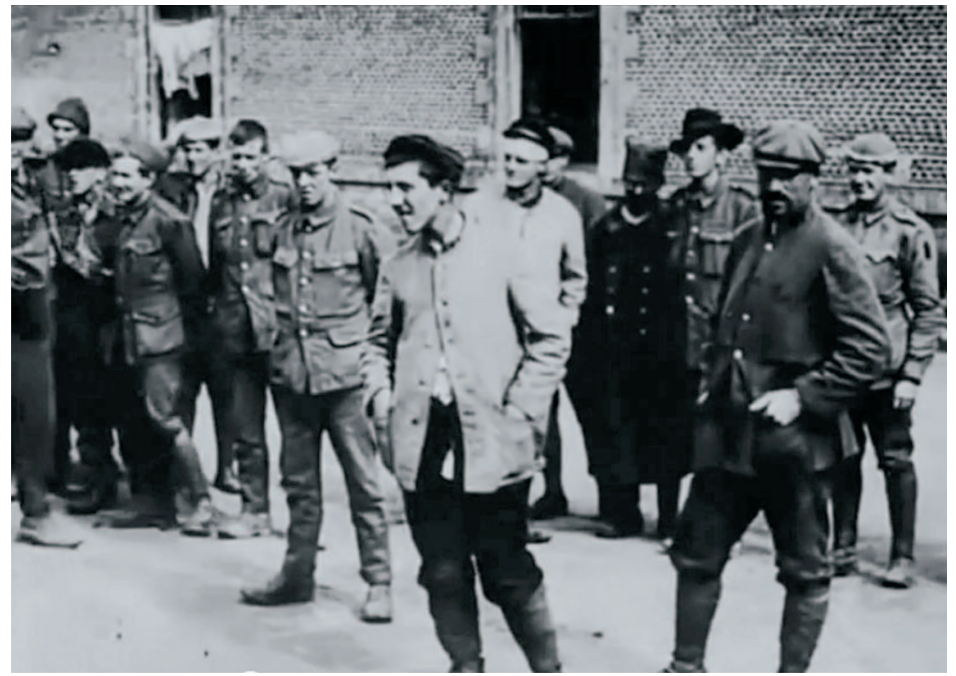

Figures 4-5. Hearts of the World (David Wark Griffith, 1918). (Sources: https:// commons.wikimedia.org/wiki/File:Hearts_of_the_World_\%281918\%29_1.jpg http://ithankyouarthur.blogspot.ca/2015_06_01_archive.html. Last accessed 04. 10. 2015.)
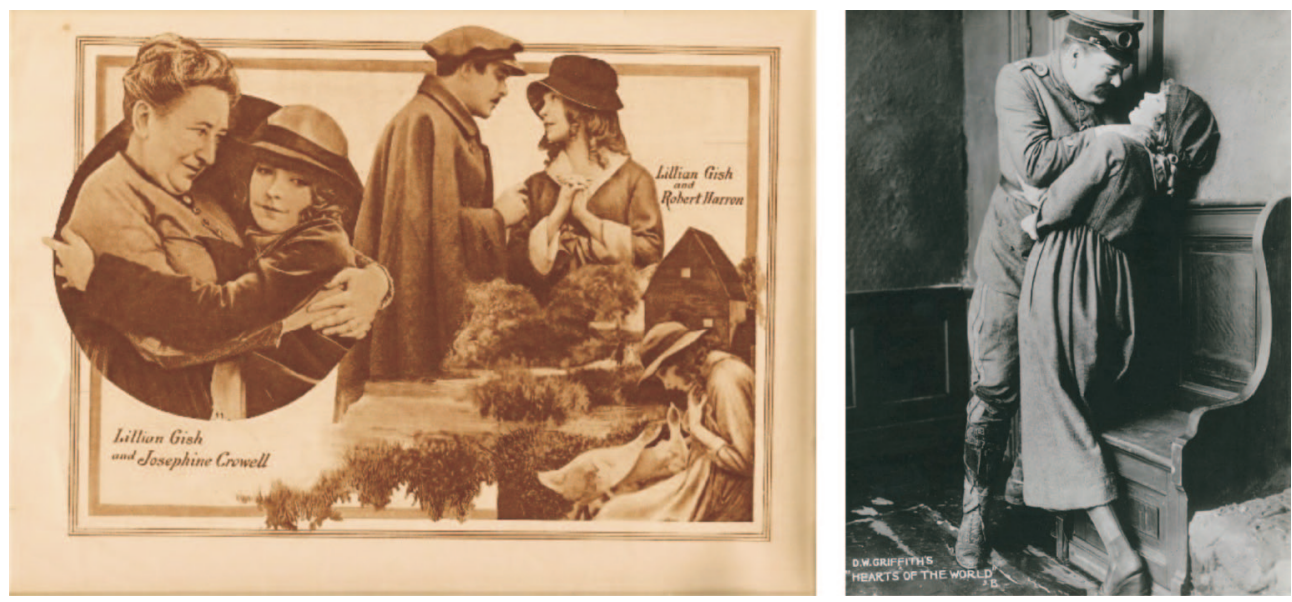
Figure 6. Repairing the front-line trench after a bomb explosion fifty yards from enemy trenches. D. W. Griffith in civilian clothing. During filming of the motion picture Hearts of the World in France, 1917, with the Canadian troops. (Source: https://commons.wikimedia.org/wiki/File:Repairing_front_line_trench_after_ bomb_explosion_fifty_yards_from_enemy_trenches._D._W._Griffith_in_civilian_ clothing._D_-_NARA_-_533726.tif. Last accessed 04. 10. 2015.)

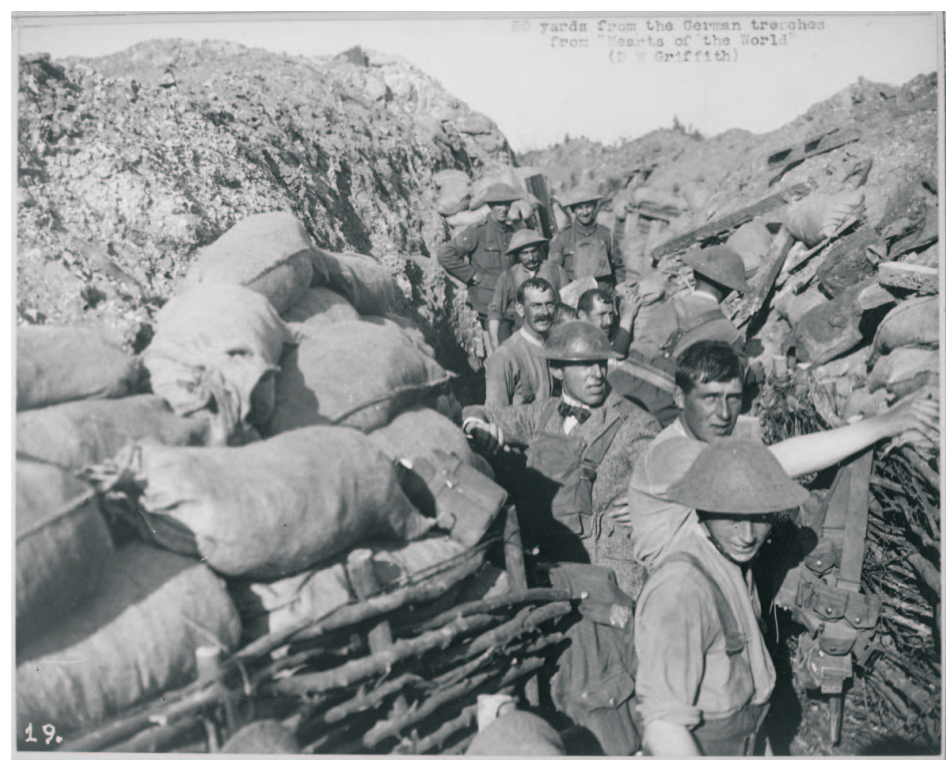

Figure 7. Ad for the American film The Heart of Humanity (1918) (Source: https://upload.wikimedia.org/wikipedia/commons/7/7a/The_Heart_of_ Humanity_\%281918\%29_-_Ad_7.jpg. Last accessed 04. 10. 2015.)

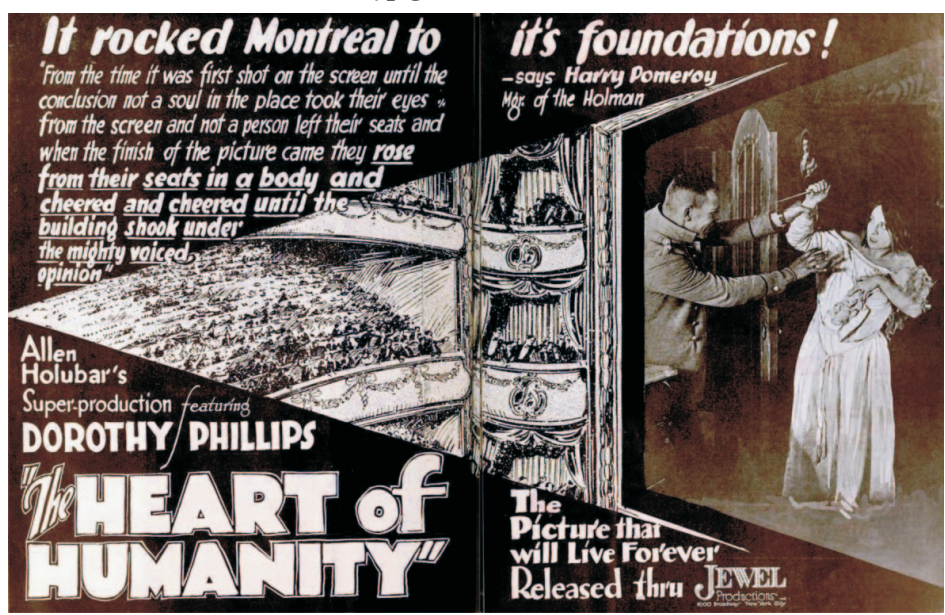

